\title{
Spring Dispersal Patterns of Red-winged Blackbirds, Agelaius phoeniceus, Staging in Eastern South Dakota
}

\author{
H. J. Homan ${ }^{1}$, G. M. Linz ${ }^{1}$, R. M. Engeman ${ }^{2}$, and L. B. Penry ${ }^{1}$ \\ ${ }^{1}$ U.S. Department of Agriculture, National Wildlife Research Center, 2110 Miriam Circle, Bismarck, North Dakota 58501- \\ 2502 USA \\ ${ }^{2}$ U.S. Department of Agriculture, National Wildlife Research Center, 4101 LaPorte Avenue, Fort Collins, Colorado $80521-$ \\ 2154 USA
}

Homan, H. J., G. M. Linz, R. M. Engeman, and L. B. Penry. 2004. Spring dispersal patterns of Red-winged Blackbirds, Agelaius phoeniceus, staging in eastern South Dakota. Canadian Field-Naturalist 118(2): 201-209.

Red-winged Blackbirds (Agelaius phoeniceus) are very abundant summer residents throughout the Prairie Pothole Region of central North America. In late summer they assemble in post-breeding flocks that cause significant amounts of agricultural damage, particularly in sunflower fields near natal sites. In April 2001, we aerially color-marked 370 000 Red-winged Blackbirds near Badger, South Dakota $\left(44^{\circ} 48^{\prime} \mathrm{N}, 97^{\circ} 21^{\prime} \mathrm{W}\right)$, to determine if migrants staging here were summer residents in sunflower production areas $\sim 350 \mathrm{~km}$ to the northwest. We measured patterns of migratory dispersal by collecting birds in 54 randomly selected blocks in the northcentral U.S. and the Prairie Provinces of Canada. The marked specimens $(n=33)$ were categorized into three polygons based on analyses of banding and re-sighting data and proximity to concentrated sunflower production. We estimated that $82 \%$ of the migrants that had staged in eastern South Dakota resided within or on the periphery of the sunflower growing area. These birds probably stay near their breeding territories until at least late August and cause early damage to sunflower, which comprises the majority of damage. Resident birds in Alberta and most of Saskatchewan (18\%) might arrive too late in the damage season to impact the sunflower crop significantly.

Key Words: Agelaius phoeniceus, Red-winged Blackbird, breeding range, color-marking, dispersal patterns, northern Great Plains, spring migration, sunflower damage.

Several million hectares of wetlands have been drained in the Prairie Pothole Region (Dahl 1990*), but high densities of semipermanent wetlands remain in North Dakota (0.88/km², Reynolds et al. 1997*). These are preferred nesting habitat of Red-winged Blackbirds (Agelaius phoeniceus) and make North Dakota the center of abundance for this species. During the mid-1990s, the breeding population in North Dakota started gaining rapidly in size. Red-winged Blackbird indices from the North American Breeding Bird Survey (BBS) are at historical highs for the state (Figure 1). From 1994-2002 North Dakota's average BBS index of all routes in the Prairie Pothole Region ranged from 199 to 250 Red-winged Blackbirds per route. North Dakota led all other U.S. states and Canadian provinces during this period in annual indices of Redwinged Blackbirds (Sauer et al. 2004*). Conflicts between wildlife and agriculture often occur because of local overabundance (Garrott et al. 1993; Conover 2002), and the growth in numbers of Red-winged Blackbirds has exacerbated a long-term struggle between sunflower producers and blackbirds (Linz and Homan 1998). Oilseed sunflower is a preferred food of Red-winged Blackbirds (Linz et al. 1984; Homan et al. 1994). It is also an important economic crop in North Dakota. In 2001, 75\% of total oilseed sunflower production in North America came from North Dakota (National Agricultural Statistics Service 2004*). With increased depredation pressure on the crop caused by population expansion of Red-winged Blackbirds, many growers probably dropped sunflowers from their field rotations (Lamey and Luecke 1994). Since 1995, the number of sunflower fields has steeply declined in central and southeastern North Dakota, areas renowned for their high levels of sunflower production (National Agricultural Statistics Service 2004*).

Statewide field damage surveys have that blackbird damage to sunflower ranges from $\$ 4$ to 11 million (U.S. dollars) in the Prairie Pothole Region (Hothem et al. 1988). Based on current population estimates and bioenergetic models, Red-winged Blackbirds cause $\$ 3$ million of the $\$ 5.5$ million lost yearly to blackbirds in the core area of sunflower production (Peer et al. 2003). Most of the damage occurs between mid-August and early September, when the calorie content of immature sunflower achenes is low and the birds must eat more to reach satiation (Cummings et al. 1989; Conner and Hall 1997). During this early damage period, when $>75 \%$ of total damage occurs, Red-winged Blackbirds account for $80 \%$ of the blackbird species observed in sunflower fields (Cummings et al. 1989). This period is before en masse blackbird migration, and the majority of these birds are of local origin. Most will remain within $200 \mathrm{~km}$ of their natal sites until molt completion (or near completion) in late August and early September (Dolbeer 1978; Besser et al. 1983; Linz et al. 1983). The damage can be quite serious in central and southeast North Dakota and northeast South Dakota, areas of concentrated production of sunflowers (National Agricultural Statistics Service 2004*) and 
plentiful wetlands to attract nesting Red-winged Blackbirds ( 22 breeding pairs $/ \mathrm{km}^{2}$, Linz et al. 2002). By late summer, the Red-winged Blackbird population responsible for most of the sunflower damage in the Prairie Pothole Region is about $39( \pm 8.8)$ million (Peer et al. 2003).

Reducing excessive field damage (e.g., $>10 \%$ per field) has proven an enormous challenge. The U.S. Department of Agriculture (USDA) uses an integrated management approach of lethal and nonlethal methods. Most of the available methods are used infrequently because of unmanageable logistics, little or no efficacy, or low cost:benefit ratios (Linz and Hanzel 1997). Mechanical frightening agents (e.g., scarecrows, pyrotechnics, and propane cannons) help alleviate light predation pressure, but only work effectively if the duration of the damage period is less than the habituation period (Cummings et al. 1986). Unfortunately, blackbirds habituate quickly to frightening agents, particularly if the crop is a preferred food in an area of limited alternate foods (Ward 1979). The taste repellent, methyl anthranilate, is also used by producers, but the concentration in the commercial product (BirdShield ${ }^{\mathrm{TM}}$ ) is below the known repellency threshold, despite the formulation's high cost (Werner et al. 2005). Experiments with avicide were tried in sunflower fields with ongoing damage. Avicide-treated rice (DRC-1339) was placed in small plots opened in the fields. This approach failed because (1) blackbirds foraged almost exclusively on the standing heads of sunflower and would not go to the ground to forage in the plots, (2) precipitation necessitated numerous rebaitings, and (3) nontarget avian risks increased substantially over the baiting period because of migration (Schaaf 2003; Linz et al. 2000). Two nonlethal methods showing some promise are reduction of dense stands of cattail (Typha spp) in wetlands near sunflower (Linz et al. 2004a) and strategic placement of lure crops to attract foraging blackbirds away from sunflower fields (Linz et al. 2004b). Cattail management has been a USDA program for over 10 years. The program is small compared to existing coverage of cattail (Ralston et al. 2004); and it also faces year-to-year logistical challenges because of instability in roost locations across years combined with cattail's ability to rapidly invade, colonize, or re-colonize wetlands (Homan et al. 2003). Research on efficacy of lure crops is just beginning and time will be needed to assess this method.

Sometimes population management may be the most realistic and effective method for reducing persistent damage caused by overabundant wildlife populations (Garrott et al. 1993). The definition of overabundance is subjective and based upon one's interests, likes, and dislikes; and therefore is controversial. It has been defined generally as that point of abundance where all positive values of the species have been overwhelmed by negative values created by the sheer numbers of individuals (Conover 2002). The definition implies both a spatial and temporal component, as populations are seldom ubiquitous or always aggregated. The definition is fitting, at least from an agricultural perspective, in the sunflower growing areas of North Dakota and northeastern South Dakota. The USDA has drafted an Environmental Impact Statement (EIS) that addresses the conflict between sunflower producers and blackbirds in North Dakota, South Dakota, and Minnesota (Federal Register 2001*). Several management options were included in the draft EIS. The research described herein addresses one of the options being considered: population management of spring migrating Redwinged Blackbirds in northeastern South Dakota. This part of South Dakota is one of the most northward sites where the population is still grouped together enough to make population management a feasible alternative.

Because blackbird damage to sunflower is a localized phenomenon occurring within the broader region of the northern Great Plains (Peer et al. 2003), it is necessary to identify specific origins of local populations before implementing any strategy of population management. Although leg-banding has provided valuable insights into migratory timing and dispersal of Red-winged Blackbirds (Dolbeer 1978), this method draws its samples randomly from regional populations. Moreover, it is labor intensive in both its capturing and ringing methods; these drawbacks combined with natural annual mortality of Red-winged Blackbirds cause data to be parsed over several years because of extremely low rates of band returns $(<0.5 \%$, Besser et al. 1983; Gammell et al. 1986; Stehn 1989). An alternative method of tracking movements, aerial mass colormarking, provides a means for rapid accumulation of data on movements of local populations within a single season framework. Recovery rates from mass colormarking projects depend on the number marked compared to the size of the study population (Johns et al. 1989); however, thousands of birds can be marked in a single application often yielding a rate of return 10 to 20 times that of leg-banding. Aerial mass colormarking has been used to track spring movements of Red-winged Blackbirds from northeastern Missouri and eastern South Dakota (Knittle et al. 1987; Knittle et al. 1996), short late-summer movements of Redwinged Blackbirds in central North Dakota (Linz et al. 1991), and movements of Red-winged Blackbirds between winter roosts in the southcentral U.S. (Harsch $1995 *$ ). The marking formulation is environmentally safe at the concentrations used (Bills and Knittle 1986; Knittle and Johns 1986).

In April 2001, we used aerial mass-marking to identify migrating Red-winged Blackbirds staging in large cattail-dominated wetlands in northeastern South Dakota. Millions of spring migrating blackbirds annually stage at this traditional stopover site between late March and April (Sawin 1999). Our objective was to assess migratory dispersal to breeding territories north of the marking site. Previous research has shown that 


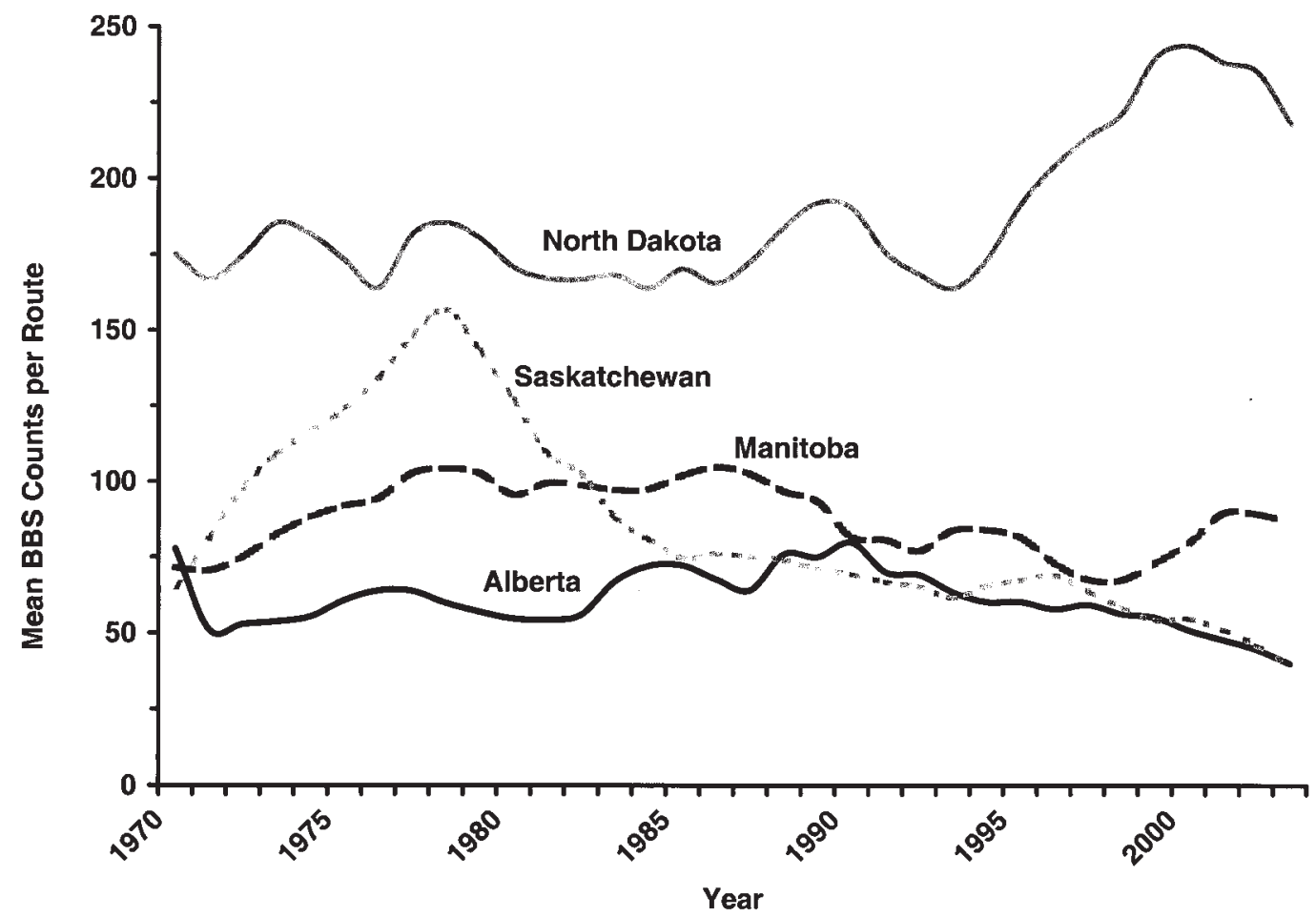

FIGURE 1. Three-year rolling averages of indices from the North American Breeding Bird Survey from 1967 to 2003 . The indices are from routes in the Drift Prairie, Glaciated Missouri Plateau, and Aspen Parklands, which are the three major physiographic regions in the Prairie Pothole Region used most frequently by Red-winged Blackbirds.

color-marked male Red-winged Blackbirds staging in eastern South Dakota during spring were in part destined for breeding grounds in or near concentrated sunflower production; however, these data were collected over 15 years ago (Knittle et al. 1987; Knittle et al. 1996). Population management programs, when used at sites far from the locality where actual damage occurs, must be based on a thorough and contemporary knowledge of movements of individual populations (Dolbeer 1978). We believed it necessary to replicate the marking studies because changes may have occurred in migratory patterns. Additionally, no data exist on dispersal movements of females, and these data would increase our understanding of the population's migration patterns.

\section{Methods \\ Marking}

During March 2001, we monitored cattail-dominated wetlands in six counties in eastern South Dakota for arrival of migratory flocks of blackbirds. Three wetlands held migratory roosts large enough (>10 000 birds) to warrant aerial mass-marking. All three roosts were within a 32-km radius of Badger, South Dakota $\left(44^{\circ} 48^{\prime} \mathrm{N}, 97^{\circ} 21^{\prime} \mathrm{W}\right)$. Roost size was estimated by counting blackbirds as they entered the roost on the evening of the spray (Meanley 1965; Arbib 1972). Species compositions and sex compositions were estimated by randomly selecting and identifying groups of individual birds as they entered (Dolbeer et al. 1978). A fixed-wing agricultural spray plane applied the marker near dark at an altitude of 20-30 m (Knittle et al. 1987). The following morning we collected birds as they departed the sprayed roost and later examined them for fluorescent marks using a long-wave $(360 \mathrm{~nm})$ ultraviolet light. We calculated the number of marked male and female Red-winged Blackbirds in the roost by multiplying the proportion of marked birds in the sample by the estimated number of males and females using the roost on the night of the spray.

The marker formulation was a 416-L solution consisting of 208 L Carboset $^{\circledR}$ (an acrylic adhesive; Noveon ${ }^{\mathrm{TM}}$ Incorporated, Cleveland, Ohio), $102 \mathrm{~L}$ foodgrade propylene glycol, $7.7 \mathrm{~kg}$ fluorescent organic pigment (DayGlo ${ }^{\circledR}$ Color Corporation, Cleveland, Ohio), $1 \mathrm{~L}$ each of a defoamer and surfactant, and $106 \mathrm{~L}$ water (Knittle et al. 1996). We used CP ${ }^{\circledR}$ nozzles set at 5 (400 micron droplets). Spray volume was $28 \mathrm{~L} / \mathrm{ha}$ delivered at $1.8 \mathrm{~kg} / \mathrm{cm}^{2}$. In spray form the solution dries in 2-3 minutes adhering to the feather surface. 
Knittle and Johns (1986) found that 5\% of marked birds lost their marks within six weeks; however, particles lodged in the barbules can remain until molt (Knittle et al. 1996; Otis et al. 1986).

\section{Sampling and Collections}

We grouped the study area into 140 blocks, each consisting of four $1^{\circ}$-latitude $\times 1^{\circ}$-longitude units. Two units were randomly selected from each block. To ensure adequate sample sizes per effort, only those units within regions that averaged $\geq 30$ Red-winged Blackbirds per BBS route were selected (Sauer et al. 2004); 37 units in Canada and 19 units in the U.S. were chosen in this manner. No units south of the $1^{\circ} \times 1^{\circ}$ unit containing the marking sites were sampled. The sample units covered an extensive area $\left(>1.0 \times 10^{6} \mathrm{~km}^{2}\right)$ bounded by $44-57^{\circ} \mathrm{N}$ latitude and $95-119^{\circ} \mathrm{W}$ longitude (Figure 2). Southwestern North Dakota, central Minnesota, central and western South Dakota, and southeastern Montana were excluded because BBS counts were $\leq 30$ (Sauer et al. 2004).

We assigned the $1^{\circ} \times 1^{\circ}$ units to one of three dispersal polygons: core, peripheral, and outside-peripheral (Figure 2). The shape and area of the polygons were based on an analysis of banding and re-sighting data, physiography, and proximity to the area of concentrated sunflower production (Stehn 1989). The core polygon encompassed the breeding range of birds having a high probability of causing early damage to sunflowers. The peripheral polygon contained the surrounding breeding range of birds that were capable (with only short pre-migratory movements) of entering the core area during the early damage period (midAugust - early September) (Dolbeer 1978; Gammell et al. 1986). The outside-peripheral polygon contained the birds farthest removed from the core area and encompassed the rest of the study area not covered by the core and peripheral polygons. The $1^{\circ} \times 1^{\circ}$ units were placed in core and peripheral polygon categories if any of the unit's area intercepted the polygon's boundary. We used a GIS to place the polygons on a georeferenced grid of the $1^{\circ} \times 1^{\circ}$ units.

We used shotguns (12-gauge with either \#6 or \#71/2 steel shot) to collect male and female Red-winged Blackbirds on breeding territories during June in the U.S. and June and early July in Canada. The wings were removed from the specimens and placed in an envelope with the GPS coordinates of the collection site. The wings were later viewed for fluorescent pigments using a 360-nm ultraviolet lamp under 1.75 magnification. The markings on tagged birds are usually subtle and invisible to the naked eye under natural light. To eliminate false positives, only splash marks and individual particles firmly attached to the feathers were considered conclusive evidence of a valid mark (Knittle et al. 1987). Blood samples were removed onsite from randomly selected specimens and used for microsatellite genetic analysis in a separate study (Williams et al. 2004). The wings were frozen and shall be kept for future research on primary feather chemistry and its relationship to geographic origins (Edwards and Smith 1984).

The data were analyzed using descriptive statistics, likelihood ratio chi-square analyses ( $G$-tests), and nonparametric tests. We used $G$-tests to assess differences between (1) the proportion of marked birds (sexes combined) in the sample with the expected proportion of marked birds in the study area; (2) the proportions of marked males and females in the sample with the expected proportions of marked males and females in the study area; and (3) the proportions of marked birds within core, peripheral, and outside-peripheral polygons. The first two tests used extrinsic expected frequencies based on estimates of marking efficiency at the staging site and population size in the study area during the breeding season. The third comparison used intrinsic frequencies generated exclusively from the collections (Sokal and Rohlf 1981). Population size in the study area was estimated using a combination of stable age structure analysis from banding data and linear regression analysis of BBS indices and independently determined density estimates (Stehn 1989). The resultant regression equation was $Y=0.3 X$, where $X$ was the average BBS count within each ecological stratum in the study area and $Y$ was the population density per km² (see Aldrich 1963; Robbins et al. 1986). We used the Wilcoxon Rank Sum test to compare ranked differences between males and females in distances traveled from the marking site to the collecting sites. Distance measurements were made using a GIS.

\section{Results}

We applied fluorescent marker seven times, tagging an estimated 235500 male and 131100 female Redwinged Blackbirds over the period 1-23 April. This period covered the Red-winged Blackbird migration through eastern South Dakota in 2001. We collected 2398 males and 2060 females on breeding territories, of which $33(0.74 \%)$ were marked (Table 1$)$. The overall recovery rate of $0.74 \%$ was similar to the expected recovery rate of $0.96 \%(G=1.1, \mathrm{P}=0.30)$, based on total number of birds marked in April and the estimated population size of breeding Red-winged Blackbirds in the sampled collection area $\left(38.1 \times 10^{6}\right.$, from Stehn 1989) which included the population in the outside-peripheral polygon. The ratio of marked males : females in the sample $(f=23: 10)$ was near the expected ratio of $22: 11(G=0.07, \mathrm{P}=0.80)$. Proportions of marked birds collected in the three polygons differed $(G=6.44, \mathrm{P}=0.04)$, with the percentages of marked birds in the core polygon $(1.03 \%)$ and peripheral polygon $(0.93 \%)$ nearly three times greater than the percentage collected in the outsideperipheral polygon $(0.35 \%)$ (Table 1$)$. The outsideperipheral polygon contributed $69 \%$ of the total $G$ value. Of the 33 marked recoveries, $15(46 \%)$ were collected in the core polygon and $12(36 \%)$ were collected in the peripheral polygon. 


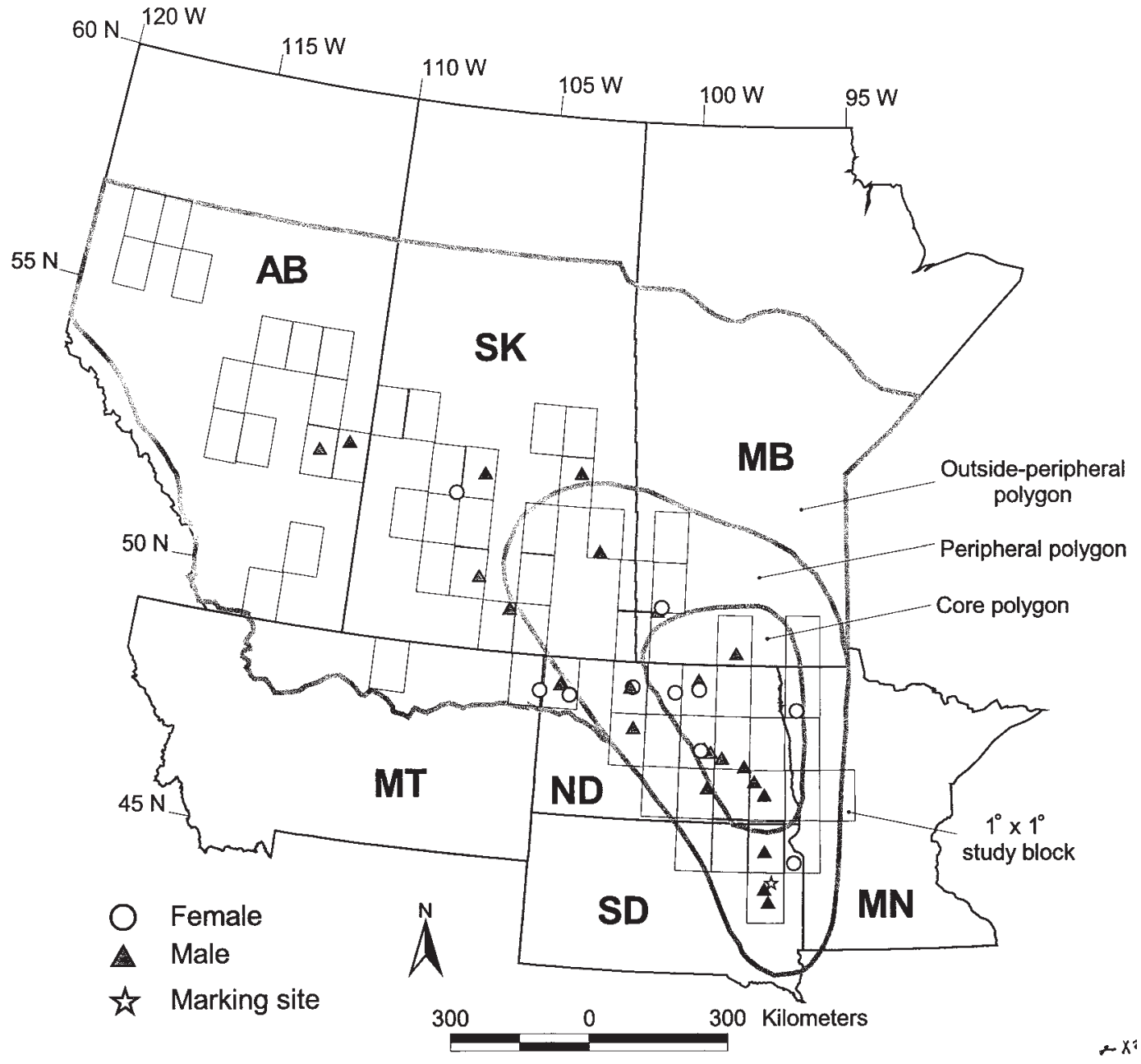

FIGURE 2. Locations of 33 marked Red-winged Blackbirds (in relation to core, peripheral- and outside-peripheral polygons) after dispersing from a spring staging site in eastern South Dakota in April 2001.

TABLE 1. Color-marked male $\left(\bigcirc^{\top}\right)$ and female () Red-winged Blackbirds collected during June and July 2001 in core, peripheral, and outside-peripheral polygons after migratory dispersal from a staging site in eastern South Dakota during April 2001.

\begin{tabular}{|c|c|c|c|c|c|c|c|c|c|c|}
\hline \multirow[b]{2}{*}{ Polygon } & \multirow[t]{2}{*}{$\begin{array}{c}\text { Number } \\
\text { units }^{\mathrm{a}} \\
\end{array}$} & \multicolumn{3}{|c|}{$\begin{array}{l}\text { Number } \\
\text { Collected }\end{array}$} & \multicolumn{3}{|c|}{$\begin{array}{l}\text { Number } \\
\text { Marked }\end{array}$} & \multicolumn{3}{|c|}{$\begin{array}{l}\text { Percent } \\
\text { Marked }\end{array}$} \\
\hline & & $0^{7}$ & 우 & Total & $0^{7}$ & ㅇ & Total & $0^{7}$ & 우 & All \\
\hline Core & 14 & 793 & 668 & 1461 & 9 & 6 & 15 & 1.13 & 0.90 & 1.03 \\
\hline Peripheral & 15 & 681 & 605 & 1286 & 10 & 2 & 12 & 1.47 & 0.33 & 0.93 \\
\hline Outside & 27 & 924 & 787 & 1711 & 4 & 2 & 6 & 0.43 & 0.25 & 0.35 \\
\hline Total & 56 & 2398 & 2060 & 4458 & 23 & 10 & 33 & 0.96 & 0.48 & 0.74 \\
\hline
\end{tabular}

a No birds were collected in two units 
No marked birds were collected north of $53^{\circ} \mathrm{N}$. Recovery distances were similar between sexes $(T=$ $0.18, \mathrm{P}=0.86)$, with the median location $519 \mathrm{~km}$ (range: $20-1353)$ from the marking sites $\left(48^{\circ} 23^{\prime} \mathrm{N}\right.$, $\left.100^{\circ} 27^{\prime} \mathrm{W}\right)$. The median azimuth from the marking sites was $325^{\circ}$. The median distance and direction of marked females placed them on the northwestern side of the core polygon $\left(48^{\circ} 23^{\prime} \mathrm{N}, 100^{\circ} 27^{\prime} \mathrm{W}\right.$; whereas, males were $70 \mathrm{~km}$ due west $\left(48^{\circ} 30^{\prime} \mathrm{N}, 101^{\circ} 23^{\prime} \mathrm{W}\right)$, in the peripheral polygon. For all recoveries combined, the median location was $50 \mathrm{~km}$ northeast of Minot, North Dakota $\left(48^{\circ} 14^{\prime} \mathrm{N}, 101^{\circ} 18^{\prime} \mathrm{W}\right)$.

\section{Discussion}

The seven sprays were evenly distributed throughout the migratory period and probably yielded an accurate depiction of the migratory distribution patterns of Red-winged Blackbirds. Similar to the results of previous banding and color-marking experiments in eastern South Dakota, our data showed that most birds followed the Prairie Pothole Region as they traveled northwest to their breeding territories (Besser et al. 1983; Knittle et al. 1987; Knittle et al. 1996). Although Red-winged Blackbirds are not confined to breeding in this region, they are found here in their highest densities. A statewide population census of breeding birds in North Dakota showed that the Prairie Pothole Region (comprised of several physiographic regions, but mainly the Drift Prairie and Glaciated Missouri Plateau) contained $70 \%$ of the state's Redwinged Blackbird population (Stewart and Kantrud 1972).

Unlike parameters such as median distance and direction, both of which can be influenced by differences in breeding densities over the study area, the proportions of marked birds within the three polygons were distribution measures mathematically independent of density. It was thus possible to consider our results as reflections of behavioral phenomena, such as fidelity to migratory pathways and philopatry. The marked population was apparently not distributing itself randomly in the study area. The low proportion of marked birds in the outside-peripheral polygon suggested that eastern South Dakota may be used mainly by migrants already near their final destination, and as a result, traveling relatively short distances after departure from the staging site. We speculate that other staging sites might exist (perhaps much farther to the west), and these should have birds destined for breeding territories in Montana, southern Alberta, and Saskatchewan. Marking of large roosts farther west (for example, a large blackbird roost exists near Great Bend, Kansas $\left[38^{\circ} 22^{\prime} \mathrm{N}, 98^{\circ} 49^{\prime} \mathrm{W}\right]$ ) may demonstrate that western migratory pathways exist distinct from the one used by blackbirds in eastern South Dakota. Certainly, the very low proportion of marked birds in the outside-peripheral polygon, compared to the other two dispersal polygons, suggests a different population of birds.
There were two other marking studies done in the general vicinity of our marking site. These were done at Lake Thompson, South Dakota $\left(44^{\circ} 23^{\prime} \mathrm{N}, 97^{\circ} 33^{\prime} \mathrm{W}\right)$, approximately $30 \mathrm{~km}$ to the southwest. Both were similar in design, scope, and sampling effort to our study, except that only males were collected. One study was conducted in 1983 (Knittle et al. 1987), the other in 1985 (Knittle et al. 1996). Even though geopolitical boundaries were used to analyze returns instead of dispersal polygons, comparisons of results among and between studies can still be made. Results were similar between our study and the 1983 study in two important facets: (1) the recovery rate of marked birds in Canada was substantially lower than the U.S. recovery rate (4.4vs. $7.0 \%$, Knittle et al. 1987), and (2) proportions of marked birds collected in western North Dakota, central North Dakota, and northeastern South Dakota were greater than other regions. By contrast, results diverged in the 1985 study, both from our results and from those from the 1983 study. The expected rate of recovery in the 1985 study was much less than the observed recovery rate $(5.2$ vs. $14.6 \%$, Knittle et al. 1996). To obtain a $14.6 \%$ recovery rate, the male population would have had to have been $6.7 \times 10^{6}$, a number $65 \%$ lower than what was estimated in the study area during that time $\left(19.0 \times 10^{6}\right.$, Stehn 1989$)$. Saskatchewan's Red-winged Blackbird population had indeed been in steep decline for nearly a decade, as evidenced by BBS indices (Figure 1); however, trends for Alberta, Manitoba, and North Dakota were either stable or increasing. It is unlikely for such a conspicuous species that a $65 \%$ decline would be missed in the BBS surveys. Of course, the number of birds marked in 1985 could have been underestimated by this magnitude, but an even more anomalous result in the 1985 study argues against this; the percentage of marked birds in Canada was greater than the percentage marked in the Prairie Pothole Region below $49^{\circ} \mathrm{N}$ (17 vs. $16 \%$ ). Usually, recovery rates are inversely related to the distance traveled from a marking site because unmarked populations arriving by other routes from other areas dilute the proportion of marked birds. Although it is conceivable that the Red-winged Blackbird population marked at Lake Thompson in 1985 migrated beyond traditional nesting areas and immigrated into Canada, perhaps seeking better wetland conditions, band recoveries collected over several decades have shown that Red-winged Blackbirds usually return to within $100 \mathrm{~km}$ of their natal sites (Nero 1956; Dolbeer 1978). If Red-winged Blackbirds were not philopatric, but nomadic or irruptive, we contend that large fluctuations in BBS counts would occur among physiographic regions comprising the Prairie Pothole Region. No significant correlations existed in yearly changes in BBS indices between North Dakota and the three Prairie Provinces within our study area, and perusal of average BBS indices over a 36-year period does not seem to indicate irregular migratory 
behavior (Figure 1). The extraordinarily high overall recovery rate of marked birds in the 1985 study may have resulted from improper identification of marks (i.e., false positives) caused by environmental contamination with fluorescence pigments used for identifying insecticide formulations and fertilizers (Knittle et al. 1987). We believe that our data from 2001 and the data from the 1983 study have provided the most accurate analyses of dispersal patterns of migrating Red-winged Blackbirds in eastern South Dakota.

\section{Summary and Conclusions}

In landscapes with numerous wetlands, blackbird damage to sunflowers averages $\geq 5 \%$ per field. Onequarter of the fields receive $>10 \%$ damage (Linz et al. 2000). At the $10 \%$ damage level, agricultural producers start dropping sunflower from their crop rotations and replacing it with other oil crops, such as soybean and canola (North Dakota Agricultural Statistics 1990*; Lamey and Luecke 1994). There is no evidence that the rapid population growth of Red-winged Blackbirds has directly affected other bird species; however, the potential for indirect effects exists. Sunflower fields were used by 49 nonblackbird species, representing all the major feeding guilds, during the late-summer and early fall migrations (Schaaf 2003). Sunflower fields have several characteristics that could make them excellent migratory stopover sites for rest, cover, and procurement of energy reserves (Hutto 1998; Petit 2000). First, they provide large blocks of sturdy herbaceous cover with a dense canopy and rank understory in a landscape that by mid-August is mostly barren north of $46^{\circ} \mathrm{N}$ because of the harvest of small grains (Schaaf 2003). Second, sunflower fields provide a diverse selection of foods, including seeds of weedy plants in the furrows and numerous invertebrates in and around the fields (Schulz 1978; Charlet et al. 1997; Schaaf 2003). This attracts avian granivores and insectivores (and of course, the carnivores). Soybean and canola fields, which often replace sunflower, have neither the beneficial vegetative structure nor the energy and are a less productive habitat for birds (Linz et al. 2004b). Moreover, these crops are "clean cropped," unlike sunflower, which is often not plowed until May of the following year. Sunflower stubble was used by 33 species of migrating birds during early spring in North Dakota (Galle et al. 2004). It was used more frequently during spring migration than fields of soybean, small grain, corn, and sorghum. Thus, loss of sunflower fields in the Prairie Pothole Region could have unforeseen ecological impacts on migrating nonblackbird species.

We estimate that $82 \%$ of the Red-winged Blackbirds that stage in eastern South Dakota during spring migration reside either within or on the periphery of the sunflower growing area. If population management of the spring breeding population in the northern Great Plains is deemed the best of the EIS alternatives, we suggest that the most efficacious strategy would be to manage the population in eastern South Dakota. Lastly, it may be possible to avoid impacting the Canadian migrants, which comprised $18 \%$ of the birds staging in eastern South Dakota, by not applying management over the entire migration. Canadian Red-winged Blackbirds should be among the last of the regional populations of Red-winged Blackbirds to arrive at the staging site (Weatherhead and Bider 1979). The arrival of Yellow-headed Blackbirds (Xanthocephalus xanthocephalus), a nontarget blackbird species, usually signifies that the Red-winged Blackbird migration is nearing its end and may be a good indicator to cease management operations.

We recommend future research on (1) genetic markers to identify local populations of Red-winged Blackbirds residing in Canada and the U.S.; (2) color-marking spring migrants in flyways farther west; (3) the relationship between timing of arrival at staging sites and distance traveled to breeding territories; and (4) color-marking pre-migratory roosts [or other means of identification, such as genetics or mineral analyses of primary feathers] northwest of the core sunflower growing area prior to fall migration.

\section{Acknowledgments}

Personnel from North Dakota/South Dakota Wildlife Services and North Dakota State University helped collect the birds. We thank the following for their support and cooperation on this project: the Departments of Agriculture of North Dakota and South Dakota; the U.S. Fish and Wildlife Service; Minnesota Department of Natural Resources; North Dakota Game and Fish Department; South Dakota Department of Game, Fish and Parks; South Dakota Department of Environment and Natural Resources; Montana Department of Fish, Wildlife and Parks; Canada Customs and Revenue Agency; Canada Department of Foreign Affairs and International Trade; the Environmental Protection Branch of Environment Canada; the Wildlife Branch of Manitoba Conservation; the Environment Branch of the Alberta Natural Resource Service; the Fish and Wildlife Branch of Saskatchewan Environment and Resource Management; the Manitoba Wildlife Animal Care Committee and Animal Care Committees within other provincial, federal, and state governments; the National Sunflower Association; and private landowners in the U.S. and Canada. Our research was conducted under the auspices of Quality Assurance Study Protocol QA-776, as amended; as such, safety guidelines, animal care, and scientific validity were reviewed, approved, and permitted by the National Wildlife Research Center, the U.S. Fish and Wildlife Service, the Environmental Protection Branch of Environment Canada, and the natural resource agencies in the states and provinces within the study area. Use of commercial products by the U.S. Government does not constitute an endorsement of these products. 
Documents Cited (marked * in text)

Dahl, Thomas E. 1990. Wetlands losses in the United States 1780 's to 1980 's. U.S. Department of the Interior, Fish and Wildlife Service, Washington, D.C., United States Geological Survey, Northern Prairie Wildlife Research Center, Jamestown, North Dakota. http://www.npwrc.usgs.gov/ resource/othrdata/wetloss/wetloss.htm (Version 16JUL97).

Federal Register. 2001. USDA, Animal Plant Health Inspection Service. Protection of sunflowers from Redwinged Blackbirds in North Dakota, South Dakota, and Minnesota. 21 May 2001, Docket Number 01-013-2.

Harsch, M. R. 1995. Dispersal patterns of blackbirds using winter roost sites in the southcentral United States. Semiannual Report (October) from North Dakota State University to Study Director of QA-401, G. M. Linz, National Wildlife Research Center, Fort Collins, Colorado, USA.

National Agricultural Statistics Service. 2004. Agricultural statistics database. http://www.nass.usda.gov:81/ipedb/.

North Dakota Agricultural Statistics Service. 1990. Blackbird evaluation survey. North Dakota State University, Fargo, North Dakota; and U.S. Department of Agriculture, Washington, D.C.

Reynolds, R. E., D. R. Cohan, and C. R. Loesch. 1997. Wetlands of North and South Dakota. Northern Prairie Wildlife Research Center, United States Geological Survey, Jamestown, North Dakota. http://www.npwrc.usgs. gov/resource/distr/others/wetstats/wetstats.htm.

Sauer, J. R., J. E. Hines, and J. Fallon. 2004. The North American Breeding Bird Survey, results and analysis 1966-2003. Version 2004.1, USGS Patuxent Wildlife Research Center, Laurel, Maryland, USA. http://www.mbrpwrc.usgs.gov/bbs/bbs.html

\section{Literature Cited}

Aldrich, J. W. 1963. Life areas of North America. Journal of Wildlife Management 27: 530-531.

Arbib, R. 1972. On the art of estimating numbers. American Birds 26: 706-712, 814.

Besser, J. F., J. W. DeGrazio, and J. L. Guarino. 1983. Seasonal movements of Red-winged Blackbirds banded in Brown County, South Dakota, 1961-1974. North American Bird Bander 8: 140-143.

Bills, T. D., and C. E. Knittle. 1986. Toxicity of Dayglo ${ }^{\circledR}$ fluorescent pigment material to four species of fish. U. S. Fish and Wildlife Service, Bird Section Research Report (359). Denver Wildlife Research Center, Denver, Colorado, USA.

Charlet, L. D., G. J. Brewer, and B. A. Franzmann. 1997. Sunflower insects. Pages 183-261 in Sunflower technology and production. Edited by A. A. Schneiter. Agronomy Monograph 35. American Society of Agronomy, Madison, Wisconsin, USA.

Conner, D. J., and A. J. Hall. 1997. Sunflower physiology. Pages 113-182 in Sunflower technology and production. Edited by A. A. Schneiter. Agronomy Monograph 35. American Society of Agronomy, Madison, Wisconsin, USA.

Conover, M. R. 2002. Resolving human-wildlife conflicts: the science of wildlife damage management. CRC Press, Boca Raton, Florida, USA.

Cummings, J. L., C. E. Knittle, and J. L. Guarino. 1986. Evaluating a pop-up scarecrow coupled with a propane exploder for reducing blackbird damage to ripening sunflower. Pages 286-291 in Proceedings of the $12^{\text {th }}$ Vertebrate Pest Conference. Edited by T. P. Salmon. University of California, Davis, California, USA.
Cummings, J. L., C. E. Knittle, and J. L. Guarino. 1989. Chronology of blackbird damage to sunflower. Wildlife Society Bulletin 17: 50-52.

Dolbeer, R. A. 1978. Movement and migration patterns of Red-winged Blackbirds: a continental overview. BirdBanding 49: 17-34.

Dolbeer, R. A., P. P. Woronecki, A. R. Stickley, Jr., and S. B. White. 1978. Agricultural impacts of a winter population of blackbirds and starlings. Wilson Bulletin 90: 3144.

Edwards, W. R., and K. E. Smith. 1984. Exploratory experiments on the stability of mineral profiles of feathers. Journal of Wildlife Management 48: 853-866.

Galle, A. M., G. M. Linz, and W. J. Bleier. 2004. Avian use of harvested crop fields during spring migration through North Dakota. Pages 405-409 in Proceedings of the $16^{\text {th }}$ International Sunflower Conference. Edited by G. Seiler. International Sunflower Association, Paris, France.

Gammell, A., R. Gammell, and J. F. Besser. 1986. Seasonal movements of Red-winged Blackbirds banded near Kenmare, North Dakota. Prairie Naturalist 18: 123-127.

Garrott, R. A., P. J. White, and C. A Vanderbilt White. 1993. Overabundance: an issue for conservation biologists. Conservation Biology 7: 946-949.

Homan, H. J., G. M. Linz, W. J. Bleier, and R. B. Carlson. 1994. Dietary comparisons of adult male Common Grackles, Red-winged Blackbirds, and Yellow-headed Blackbirds in north central North Dakota. Prairie Naturalist 26: 273-281.

Homan, H. J., G. M. Linz, R. C. Carlson, and W. J. Bleier. 2003. Spring distribution of Ring-necked Pheasants (Phasianus colchicus) following cattail reduction with glyphosate herbicide. Wildlife Research 30: 159-166.

Hothem, R. L., R. W. DeHaven, and S. D. Fairaizl. 1988. Bird damage to sunflower in North Dakota, South Dakota, and Minnesota, 1979-1981. U.S. Department of the Interior, Fish and Wildlife Service Technical Report (15), Washington, D.C.

Hutto, R. L. 1998. On the importance of stopover sites to migrating birds. Auk 115: 823-825.

Johns, B. E., R. L. Bruggers, and M. M. Jaeger. 1989. Mass-marking quelea with fluorescent pigment particles. Pages 50-60 in Quelea quelea, Africa's bird pest. Edited by R. L. Bruggers and C. C. H. Elliot. Oxford University Press, Oxford, UK.

Knittle, C. E., and B. E. Johns. 1986. Field-spray comparison of two particle-marker formulations used to massmark Red-winged Blackbirds. U. S. Fish and Wildlife Service, Bird Section Research Report (317), Denver Wildlife Research Center, Denver, Colorado, USA.

Knittle, C. E., G. M. Linz, B. E. Johns, J. L. Cummings, J. E. Davis, Jr., and M. M. Jaeger. 1987. Dispersal of male Red-winged Blackbirds from two spring roosts in central North America. Journal of Field Ornithology 58: 490-498.

Knittle, C. E., G. M. Linz, J. L. Cummings, J. E. Davis, Jr., B. E. Johns, and J. F. Besser. 1996. Spring migration patterns of male Red-winged Blackbirds (Agelaius phoeniceus) from two migratory roosts in South Dakota and Minnesota. American Midland Naturalist 136: 134-142.

Lamey, H. A., and J. L. Luecke. 1994. Preliminary results of the 1994 grower survey of pest problems and pesticide use in Kansas, Minnesota, North Dakota and South Dakota. North Dakota State University Extension Service, Fargo, North Dakota, USA. 
Linz, G. M., S. B. Bolin, and J. F. Cassel. 1983. Postnuptial and postjuvenal molts of Red-winged Blackbirds in Cass County, North Dakota. Auk 100: 206-209.

Linz, G. M., and J. J. Hanzel. 1997. Birds and sunflower. Pages 381-394 in Sunflower technology and production. Edited by A. A. Schneiter. Agronomy Monograph 35. American Society of Agronomy, Madison, Wisconsin, USA.

Linz, G. M., and H. J. Homan. 1998. Tracing the history of blackbird research through an industry's looking glass: the Sunflower Magazine. Pages 35-42 in Proceedings of the $18^{\text {th }}$ Vertebrate Pest Conference. Edited by R. O. Baker and A. C. Crabb. University of California, Davis, California, USA.

Linz, G. M., H. J. Homan, R. L. Wimberly, P. Mastrangelo, and W. J. Bleier. 2004a. Management of cattail (Typha spp.) stands with glyphosate to disperse blackbirds. Pages 411-416 in Proceedings of the $16^{\text {th }}$ International Sunflower Conference. Edited by G. Seiler. International Sunflower Association, Paris, France.

Linz, G. M., C. E. Knittle, J. L. Cummings, J. E. Davis, Jr., D. L. Otis, and D. L. Bergman. 1991. Using aerial marking for assessing population dynamics of late summer roosting Red-winged Blackbirds. Prairie Naturalist 23: $117-126$.

Linz, G. M., B. D. Peer, H. J. Homan, R. L. Wimberly, D. L. Bergman, and W. J. Bleier. 2002. Has an integrated pest management approach reduced blackbird damage to sunflower? Pages 132-137 in Human conflicts with wildlife: economic considerations. Edited by L. Clark. National Wildlife Research Center, Fort Collins, Colorado, USA.

Linz, G. M., D. A. Schaaf, P. Mastrangelo, H. J. Homan, L. B. Penry, and W. J. Bleier. 2004b. Wildlife conservation sunflower plots as a dual-purpose wildlife management strategy. Pages 291-294 in Proceedings of the 21 $1^{\text {st }}$ Vertebrate Pest Conference, Edited by R. M. Timm and W. P. Gorenzel, University of California, Davis, California, USA.

Linz, G. M., D. A. Schaff, R. L. Wimberly, H. J. Homan, T. L. Pugh, B. D. Peer, P. Mastrangelo, and W. J. Bleier. 2000. Efficacy and potential nontarget impacts of DRC-1339 avicide use in ripening sunflower fields: 1999 progress report. Pages 162-169 in Proceedings of the $22^{\text {nd }}$ Annual Sunflower Research Workshop. Fargo, North Dakota, USA.

Linz, G. M., D. L. Vakoch, J. F. Cassel, and R. B. Carlson. 1984. Food of Red-winged Blackbirds, Agelaius phoeniceus, in sunflower fields and corn fields. Canadian FieldNaturalist 98: 38-44.

Meanley, B. 1965. The roosting behavior of the Red-winged Blackbird in the southern United States. Wilson Bulletin 77: 217-228.

Nero, R. W. 1956. A behavior study of the Red-winged Blackbird: I. Mating and nesting activities. Wilson Bulletin 68: 5-37.

Otis, D. L., C. E. Knittle, and G. M. Linz. 1986. A method for estimating turnover in spring blackbird roosts. Journal of Wildlife Management 50: 567-571.
Peer, B. D., H. J. Homan, G. M. Linz, and W. J. Bleier. 2003. Impact of blackbird damage to sunflower: bioenergetic and economic models. Ecological Applications 13: 248-256.

Petit, D. R. 2000. Habitat use by landbirds along nearcticneotropical migration routes: implications for conservation of stopover habitats. Studies in Avian Biology 20: 15-33.

Ralston, S. T., G. M. Linz, and W. J. Bleier. 2004. Quantification of cattail (Typha spp.) in the Prairie Pothole Region of North Dakota in relation to blackbird damage to sunflower. Pages 417-422 in Proceedings of the $16^{\text {th }}$ International Sunflower Conference. Edited by G. Seiler. International Sunflower Association, Paris, France.

Robbins, C. S., D. Bystrak, and P. H. Geissler. 1986. The Breeding Bird Survey: its first fifteen years, 1965-1979. United States Department of the Interior, Fish and Wildlife Service Publication (157), Washington, D.C.

Sawin, R. S. 1999. Habitat characteristics of spring blackbird roosts in eastern South Dakota. M.S. thesis, North Dakota State University, Fargo, North Dakota, USA.

Schaaf, D. A. 2003. Avian use of ripening sunflower fields in North Dakota. M.S. thesis, North Dakota State University, Fargo, North Dakota, USA.

Schulz, J. T. 1978. Insect pests. Pages 169-223 in Sunflower science and technology. Edited by J. F. Carter. Agronomy Monograph 19. American Society of Agronomy, Madison, Wisconsin, USA.

Sokal, R. R., and F. J. Rohlf. 1981. Biometry: the principles and practice of statistics in biological research. Second edition. W. H. Freeman and Company, New York, New York, USA.

Stehn, R. A. 1989. Population ecology and management strategies for Red-winged Blackbirds. U. S. Fish and Wildlife Service, Bird Section Research Report (432), Denver Wildlife Research Center, Denver, Colorado, USA.

Stewart, R. A., and H. A. Kantrud. 1972. Population estimates of breeding birds in North Dakota. Auk 89: 766-788.

Ward, P. 1979. Rational strategies for the control of queleas and other migrant bird pests in Africa. Philosophical Transactions of the Royal Society, London 287: 289-300.

Weatherhead, P.J., and J. R. Bider. 1979. Management options for blackbird problems in agriculture. Phytoprotection 60: 145-155.

Werner, S. J., H. J. Homan, M. L. Avery, G. M. Linz, E. A. Tillman, T. Slowik, R. W. Byrd, T. M. Primus, and M. J. Goodall. 2005. Evaluation of Bird Shield ${ }^{\mathrm{TM}}$ as a blackbird repellent in ripening rice and sunflower fields. Wildlife Society Bulletin 33(1): In Press.

Williams, C. L., H. J. Homan, J. J. Johnston, and G. M. Linz. 2004. Microsatellite variation in Red-winged Blackbirds (Agelaius phoeniceus). Biochemical Genetics 42: $35-41$.

Received 30 July 2002

Accepted 29 October 2004 